\title{
ANALISIS FAKTOR-FAKTOR STRUKTUR MODAL PADA PERUSAHAAN FOOD AND BEVERAGE DI BURSA EFEK INDONESIA (BEI) PERIODE 2017-2019
}

\author{
Niken Wahyu $\mathbf{C}^{1}$, Adilah Permananingrum ${ }^{2}$, Isnaeni Yulianti ${ }^{3}$ \\ 1,2,3Universitas Pancasakti Tegal, nikencahyaningtyas@gmail.com; adilah.daewoo@gmail.com; \\ Isnaeni595@gmail.com
}

\begin{abstract}
ABSTRAK
Penelitian ini bertujuan untuk menguji dan menganalisa faktor-faktor yang mempengaruhi struktur modal perusahaan food and beverage yang terdaftar di Bursa Efek Indonesia (BEI) periode 2017-2019. Data yang diperoleh diambil dari Bursa Efek Indonesia melalui situs resmi www.idx.co.id. Data penelitian dari 6 perusahaan yang sesuai kriteria penelitian dengan jumlah 72 data observasi. Metode penelitian yang digunakan dalam penelitian ini adalah analisis regresi linear berganda dengan alat bantu SPSS versi 25.0. SPSS (Statistical Package for Social Sciences). Hasil penelitian menunjukkan bahwa variabel struktur modal mampu dijelaskan oleh variabel yang diteliti yaitu likuiditas, pertumbuhan penjualan, ukuran perusahaan dan struktur asset meskipun dengan hasil yang tidak cukup besar. Hasil penelitian menunjukkan variabel likuiditas dan pertumbuhan penjualan berpengaruh positif signifikan terhadap struktur modal. Sedangkan variabel ukuran perusahaan dan struktur aset tidak berpengaruh terhadap struktur modal perusahaan. Dan secara simultan (bersama sama) semua variabel berpengaruh terhadap struktur modal perusahaan. Perkembangan industri yang cepat mengharuskan perusahaan lebih fleksibel menyesuaikan struktur modalnya agar memenangkan persaingan yang kompetitif. Keseimbangan modal internal dan eksternal menjadi kunci keberhasilan perusahaan. Keberhasilan pengelolaan struktur modal dapat meningkatkan kinerja perusahaan.
\end{abstract}

Kata Kunci: Struktur Modal, Likuiditas, Pertumbuhan Penjualan, Ukuran Perusahaan, Struktur Asset

\begin{abstract}
This study aims to examine and analyze the factors that influence the capital structure of food and beverage companies listed on the Indonesia Stock Exchange (IDX) for the 2017-2019 period. Data obtained from the Indonesia Stock Exchange through the official website www.idx.co.id. Research data from 6 companies that fit the research criteria with a total of 72 observational data. The research method used in this study is multiple linear regression analysis with SPSS version 25.o as a tool. SPSS (Statistical Package for Social Sciences). The results showed that the capital structure variable could be explained by the variables studied, namely liquidity, sales growth, company size and asset structure even though the results were quite large. The result showed that liquidity and growth variables had a significant positive effect on capital structure. Meanwhile, firm size and asset structure variables have no effect on the company's capital structure. And simultaneously (together) All variables have an effect on the company's capital structure.The fast industrial development requires companies to be more flexible in adjusting their capital structure in order to win competitive competition. The balance of internal and external capital is the key to the company's success. Successful management of capital structure can improve company performance.
\end{abstract}

Keywords: Capital Structure, Liquidity, Sales Growth, Company Size, Asset Structure 
Naskah diterima : 16-04-2021, Naskah dipublikasikan : 30-11-2021

\section{PENDAHULUAN}

Indonesia menjadi salah satu negara dengan penduduk terbanyak di dunia merupakan target pasar potensial sekaligus target investasi para investor. Tingkat konsumsi baik makanan dan minuman meningkat. Hal ini pun berpengaruh terhadap perkembangan sektor industri terutama perusahaan sub sektor food and beverage yang terdaftar di Bursa Efek Indonesia (BEI).

Imbas krisis global pada tahun 2010 sempat berimbas ada perkembangan seluruh perusahaan sub sektor food and beverage yang terdaftar di Bursa Efek Indonesia (BEI). Pertumbuhan sektor food and beverage ini mengalami penurunan cukup drastis dari $8,84 \%$ menjadi $2,73 \%$. Semakin tingginya harga bahan baku menjadikan tingginya biaya produksi yang pada akhirnya memicu kenaikan harga jual produk. Jika hal ini terus berlanjut akan menurunkan daya saing perusahaan sub sektor food and beverage karena harga produk mahal dan kalah bersaing dengan produk dari luar negeri sekaligus menurunkan laba perusahaan. Salah satu perusahaan yang merasakan dampak krisis global.

Kondisi pertumbuhan ekonomi dan konsumsi rumah tangga di Indonesia melambat di bawah rata-rata. Hal ini tergambar dari grafik berikut :

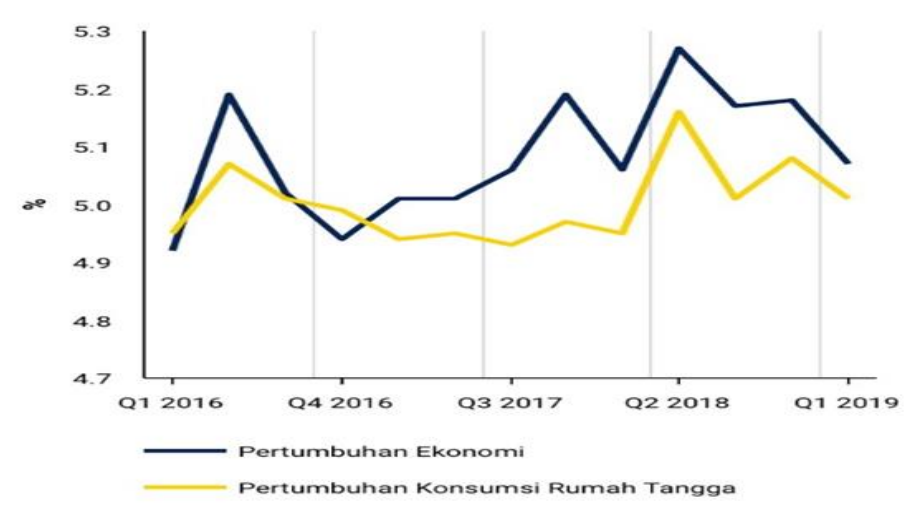

Sumber : Badan Pusat Statistik

Gambar 1. Pertumbuhan Ekonomi dan Konsumsi Rumah Tangga

Melambat dibawah Rata-Rata

Melambatnya pertumbuhan ekonomi pada kuartal 1 tahun 2019 menunjukkan konsumsi masyarakat yang menurun. Kondisi ini berdampak pada penurunan kinerja sektor keuangan perusahaan sub sector food and beverage di Indonesia. Salah satu contohnya perusahaan raksasa Unilever dan beberapa perusahaan lainnya.

Pertumbuhan ekonomi Indonesia pada tahun 2019 tumbuh 5,02\% yang berarti tumbuh negative $0,15 \%$ dibandingkan periode tahun lalu 2018 pertumbuhan ekonomi sebesar 5,17\%. Hal ini bisa dipastikan salah satu akibat melambatnya pertumbuhan konsumsi rumah tangga. Konsumsi rumah tangga merupakan penopang utama perkembangan sektor ekonomi justru tumbuh semakin melandai sepanjang tahun 2019. Dari data statistic diketahui bahwa pertumbuhan ekonomi setiap kuartal sepanjang tahun 2019 mengalami penurunan yaitu dari kuartal 1 sebesar 5,02\%, kuartal 2 sebesar 5,18\%, kuartal 3 sebesar 5,01\% dan turun pada kuartal 4 sebesar $4,99 \%$. Permasalahan ini perlu untuk segera ditangani pemerintah untuk meningkatkan daya beli masyarakat secara keseluruhan.

Peran struktur modal perusahaan menjadi inti yang penting bagi perkembangan usaha dari perusahan itu sendiri. Perusahaan dapat memenuhi kebutuhan modalnya dari sumber internal dan sumber eksternalnya. Keputusan struktur modal merupakan keputusan paling signifikan yang 
dihadapi perusahaan. (Nguyen \& Nguyen, 2020). Berbagai penelitian mengenai faktor-faktor yang mempengaruhi struktur modal sudah dilakukan selama ini dan menghasilkan beberapa kesimpulan yang berbeda. Penelitian (Sikveland \& Zhang, 2020) menyatakan bahwa profitabilitas dan likuiditas berpengaruh terhadap struktur modal perusahaan yang diukur menggunakan hutang jangka pendek, hutang jangka panjang, dan total hutang. Penelitian (Yildirim et al., 2018) menyatakan bahwa faktor-faktor yang mempengaruhi struktur modal diantaranya adalah profitabilitas, tingkat pertumbuhan (growth opportunity), ukuran perusahaan (Size), tangibility (Tang), resiko bisnis (business risk) dan pendapatan domestik bruto (GDP). Sedangkan penelitian dari (Khémiri \& Noubbigh, 2018) menyatakan bahwa faktor faktor yang mempengaruhi struktur modal diantaranya adalah profitabilitas, pertumbuhan perusahaan, tingkat investasi (Investment rate), Jaminan (Tangibility) dan Pajak Perusahaan (Non Debt Tax Shield).

Tujuan utama dari penelitian ini menguji variabel likuiditas, pertumbuhan perusahaan, ukuran perusahaan dan struktur aktiva mempengaruhi tingkat struktur modal perusahaan food and beverage yang terdaftar di Bursa Efek Indonesia (BEI) periode tahun 2017-2019.

\section{KAJIAN LITERATUR \\ Struktur Modal}

Struktur modal sangat penting untuk perusahaan bagi meningkatkan kemampuan perusahaan dalam memenuhi kebutuhan stakeholders. Teori struktur modal diawali oleh Modigliani Miller tahun 1958 yang menyatakan bahwa pada pasar yang sempurna, nilai perusahan tidak dipengaruhi oleh struktur modalnya. Pada kenyataannya tidak ada pasar yang sempurna, sehingga (Miller, 1963) merevisi pendapatnya dengan menyatakan konsep penghematan pajak dapat meningkatkan nilai perusahaan. Manfaat hutang untuk perisai pajak dari penurunan pendapatan yang dikarenakan pembayaran bunga hutang. Untuk menjelaskan mengenai struktur modal direkomendasikan tiga teori utama yaitu teori trade off, teori pecking order dan teori keagenan. Teori trade off atau Balancing Theory dikembangkan pada awalnya oleh (Kraus \& Litzenberger, 1973) menyatakan bahwa perusahaan akan menukar biaya dan manfaat dari hutang untuk memaksimalkan nilai perusahaan. Teori pecking order disampaikan oleh (Myers, 1983) menyatakan bahwa urutan pendanaan perusahaan mengikuti hirarki diawali oleh pendanaan internal, pendanaan eksternal kemudian ekuitas diterbitkan saat tidak ada lagi hutang yang bisa diusahakan oleh perusahaan. Teori keagenan dinyatakan oleh (Jensen, 1986) yang menyatakan bahwa struktur modal yang optimal dapat memaksimalkan nilai perusahaan haruslah mampu meminimalkan konflik antara pemangku kepentingan.

\section{Likuiditas (Liquidity)}

Menurut (Brigham dan Houtson, 2011:134) Likuiditas merupakan perbandingan antara aktiva lancar dengan hutang lancar. Dimana kewajibannya aset yang diperdagangkan di pasar aktif sehingga dapat dikonversi dengan cepat menjadi kas pada harga pasar yang berlaku. Suatu analisis likuiditas penuh membutuhkan penggunaan anggaran kas, karena untuk membayar utangnya (kewajibannya) pada saat jatuh tempo. Perusahaan yang memiliki tingkat likuiditas tinggi dengan kemampuan mengembalikan kewajibannya diharapkan mampu mendapatkan hutang lebih tinggi. Ada dua hasil penelitian mengenai likuiditas yaitu 1. Apabila perusahaan mampu memenuhi kewajibannya maka disebut perusahaan likuid, 2. Apabila perusahaan tidak mampu memenuhi kewajibannya disebut perusahaan likuid.

\section{Pertumbuhan Perusahaan (Growth Opportunity)}

Rasio pertumbuhan (Growth ratio) memberikan kejelasan kemampuan perusahaan dalam mempertahankan posisi pertumbuhan perusahaan dan sektor usahanya. Pertumbuhan perusahaan meliputi pertumbuhan penjualan, laba bersih, pendapatan per saham, dividen per saham. Perusahaan yang memiliki pertumbuhan penjualan yang kuat mampu mengakses dana eksternal lebih tinggi untuk memenuhi kebutuhan investasi modalnya (Kasmir, 2015:114). 


\section{Ukuran Perusahaan (Size)}

Ukuran perusahaan menjadi penentu dalam hubungannya dengan struktur modal. Ukuran perusahaan dapat diukur menggunakan total asset yang dimiliki perusahaan. Karena nilai total asset bernilai besar maka akan digunakan logaritma total asset untuk memudahkan pengukurannya. Semakin besar ukuran perusahaan yang berarti memiliki aset yang besar diharapkan mampu mendapatkan lebih banyak hutang. (Ramli et al., 2019).

\section{Struktur Aktiva}

Struktur aktiva merupakan perbandingan antara aktiva tetap terhadap total asset yang dimiliki perusahaan dalam bentuk persentase. Dimana perusahaan yang memiliki aktiva tetap yang besar atau aktiva berwujud yang besar akan memiliki kesempatan mendapatkan tingkat hutang yang lebih tinggi. Aset berwujud memberikan jaminan keamanan bagi calon investor.(Yildirim et al., 2018)

\section{Kerangka Pikir dan Hipotesis}

Likuiditas didefinisikan sebagai rasio antara aset lancar (current assets) terhadap kewajiban lancar (current liabilities). Perusahaan dalam posisi likuid mampu memenuhi kewajiban jangka pendeknya. Perusahaan yang tingkat likuiditasnya besar diharapkan mampu meningkatkan tingkat hutangnya. Ini menyiratkan hubungan yang positif posisi likuiditas dengan tingkat hutang perusahaan. Perusahaan dengan tingkat likuiditas tinggi menunjukkan posisi keuangan kuat dan kinerja perusahaan yang baik serta mampu menghadapi kewajiban keuangan baik jangka pendek maupun jangka panjang. Hasil penelitian (Vo, 2017) menyatakan terdapat hubungan positif signifikan likuiditas terhadap struktur modal. Namun demikian likuiditas yang tinggi bila tidak menjamin perusahaan akan menggunakan kesempatan ini untuk meningkatkan hutangnya dan lebih menggunakan dana internal. Hal ini sesuai dengan penelitian (Mishra \& Dasgupta, 2019), (Ramli et al., 2019), (Gunardi et al., 2020). Berdasarkan penjelasan diatas maka hipotesis pertama yang kami ajukan sebagai berikut:

\section{H1: Likuiditas berpengaruh signifikan terhadap struktur modal}

Pertumbuhan perusahaan yang baik akan memberikan kesempatan perusahaan mendapatkan tingkat hutang yang tinggi. Dalam hal ini diukur dengan pertumbuhan penjualan perusahaan. Menurut teori keagenan, struktur modal akan menggunakan lebih sedikit hutang dalam pembiayaan perusahaan ketika peluang pertumbuhan baik. Hal ini dilakukan untuk mengurangi konflik keagenan antara agen dan investor. Menurut teori ini kekuatan dari manajer meningkat dan meningkatkan kinerja perusahaan. Bagaimanapun peluang pertumbuhan yang tinggi merupakan indikasi kinerja bisnis yang sehat dan sukses. Hasil penelitian (Yildirim et al., 2018), (Sikveland \& Zhang, 2020) menunjukkan hubungan positif antara pertumbuhan perusahaan terhadap tingkat hutang perusahaan. Sedangkan tingkat pertumbuhan perusahaan yang tinggi juga bisa membuat perusahaan lebih menggunakan dana internal dalam kegiatannya.Hal ini sesuai dengan penelitian (Zhang \& Liu, 2017), (Ramli et al., 2019), (Panda \& Nanda, 2020) Berdasarkan uraian di atas maka hipotesis kedua yang kami ajukan sebagai berikut:

\section{H2: Pertumbuhan penjualan berpengaruh signifikan terhadap struktur modal}

Ukuran perusahaan merupakan salah satu faktor penentu peningkatan kinerja perusahaan. Pengukuran ukuran perusahaan menggunakan logaritma total asset. Ukuran perusahaan yang lebih besar memiliki variasi kapabilitas lebih besar, skala ekonomi lebih besar, memungkinkan terjadi peningkatan kinerja perusahaan dan mendapatkan tingkat hutang yang lebih tinggi (Nguyen \& Nguyen, 2020). Hasil penelitian dari (Bilgin \& Dinc, 2019) dan (Yildirim et al., 2018) menyatakan terdapat hubungan positif antara ukuran perusahaan terhadap struktur modal. Berdasarkan uraian di atas maka hipotesis ketiga yang kami ajukan sebagai berikut:

\section{H3: Ukuran Perusahaan berpengaruh signifikan terhadap struktur modal.}


Struktur asset dapat digunakan sebagai jaminan hutang. Besarnya tingkat hutang tergantung dari besarnya aset yang dijadikan jaminan. Agunan relative atau rasio dari asset tetap dibanding total asset seringkali dijadikan ukuran dari struktur asset. Karena aset tetap adalah asset jangka panjang tidak lancar, maka pemberi pinjaman akan mempertimbangkan memperpanjang pinjaman jangka panjang. Hasil penelitian dari (Sikveland \& Zhang, 2020), (Sikveland \& Zhang, 2020) menyatakan bahwa terdapat hubungan positif struktur asset terhadap struktur modal. Berdasarkan uraian diatas maka hipotesis keempat yang kami ajukan sebagai berikut:

\section{H4: Struktur Asset berpengaruh signifikan terhadap struktur modal.}

Teori Pecking order mendukung pernyataan bahwa peluang pertumbuhan semakin meningkat disebabkan timbulnya asimetri informasi dimana agen memiliki informasi lebih banyak mengenai perusahaan. Agen berusaha melakukan investasi untuk meningkatkan laba perusahaan. Dibutuhkan sumber dana yang besar untuk membiayai investasi, sumber dana ini berasal dari internal dan eksternal untuk mencukupi kebutuhan sumber dana. Sedangkan efek ukuran perusahaan mempengaruhi struktur modal perusahaan. Dilihat dari Teori Trade off bahwa hubungan positif dapat diharapkan dari ukuran perusahaan terhadap tingkat hutang perusahaan. Semakin besar perusahaan amaka volatilitas arus kas semakin besar dan peluang mendapatkan hutang lebih tinggi. tingkat kegagalan perusahaan lebih rendah.(Yildirim et al., 2018). Menurut teori Trade off bahwa likuiditas semakin tinggi maka perusahaan memiliki kemampuan membayar hutang lebih baik. Dipastikan dengan tingkat likuiditas tinggi, perusahaan memperoleh kesempatan mendapatkan hutang yang lebih besar. Menurut teori trade off dan teori pecking order menyatakan hubungan positif antara struktur aktiva atau aset yang dijadikan jaminan dengan tingkat hutang. bahwa semakin tinggi asset yang dapat dipertanggungjawabkan maka semakin tinggi tingkat hutang yang dapat diperoleh perusahaan.(Khémiri \& Noubbigh, 2018). Berdasarkan uraian di atas maka kami mengajukan hipotesis kelima sebagai berikut:

H5: Likuiditas, Ukuran perusahaan, Tingkat Pertumbuhan dan Struktur asset secara bersama sama berpengaruh signifikan terhadap struktur modal

Keterkaitan antara likuiditas, ukuran perusahaan, tingkat pertumbuhan dan struktur asset secara sistematis dapat digambarkan dalam kerangka pikir sebagai berikut:

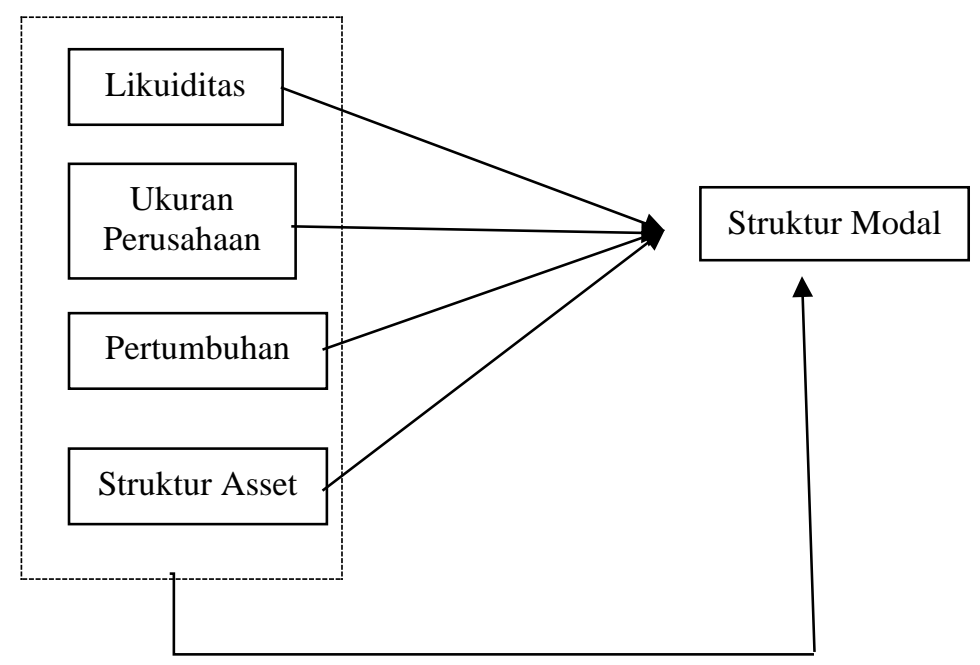

Gambar 2. Kerangka Pemikiran 


\section{METODE PENELITIAN}

Populasi dalam penelitian ini adalah seluruh perusahaan Food and Beverage yang terdaftar di Bursa Efek Indonesia (BEI) sebanyak 26 perusahaan. Sampel dalam penelitian ini adalah sebagian dari perusahaan food and beverage yang terdaftar di Bursa Efek Indonesia sebanyak 6 perusahaan. Perusahaan tersebut memenuhi kriteria yang ditetapkan diantaranya melakukan laporan keuangan berturut turut selama periode penelitian yaitu tahun 2017-2019, menggunakan mata uang rupiah dalam pelaporan keuangannya dan dalam data tersebut memuat variabel yang akan diteliti.

Tabel 1. Operasionalisasi Variabel

\begin{tabular}{|c|c|c|c|}
\hline Variabel & Skala & Definisi & Pengukuran \\
\hline Likuiditas & $\begin{array}{l}\text { Current } \\
\text { ratio }\end{array}$ & $\begin{array}{lr}\text { Rasio antara aktiva } \\
\text { lancar terhadap utang } \\
\text { lancar, } & \text { dalam } \\
\text { presentase. } & \end{array}$ & $\frac{\text { Aktiva Lancar }}{\text { Utang Lancar }} \times 100 \%$ \\
\hline $\begin{array}{l}\text { Pertumbuhan } \\
\text { Penjualan }\end{array}$ & $\mathrm{TP}$ & $\begin{array}{lr}\text { Rasio antara total } \\
\text { penjualan tahun ini } \\
\text { dikurangi } & \text { tahun } \\
\text { sebelumnya dibagi } \\
\text { total penjualan } & \text { tahun } \\
\text { sebelumnya } & \end{array}$ & $\begin{array}{l}\text { TP } \\
=\frac{\text { Total Penjualan } t-\text { Total Penju }}{\text { Total Penjualan } t-1}\end{array}$ \\
\hline $\begin{array}{l}\text { Ukuran } \\
\text { perusahaan }\end{array}$ & $\begin{array}{l}\text { Firm } \\
\text { size }\end{array}$ & $\begin{array}{l}\text { Rasio log aktiva lancar, } \\
\text { dalam presentase. }\end{array}$ & Ln Total Aktiva \\
\hline Struktur Asset & SA & $\begin{array}{l}\text { Rasio antara aktiva } \\
\text { tetap yang dimiliki } \\
\text { perusahaan terhadap } \\
\text { total aset, dalam } \\
\text { presentase. }\end{array}$ & $\frac{\text { Aktiva Tetap }}{\text { Total Aset }} \times 100 \%$ \\
\hline
\end{tabular}

Sumber: Penelitian sebelumnya

Metode analisis data dalam penelitian ini adalah dengan menggunakan metode analisis data kuantitatif dengan menggunakan metode analisis regresi linear berganda. Metode regresi linear berganda digunakan untuk menguji apakah ada pengaruh variabel independen terhadap variabel dependen. Alat analisis data yang digunakan adalah SPSS versi 25.0. SPSS (Statistical Package for Social Sciences). Analisis yang digunakan pada penelitian ini yaitu, analisis statistik deskriptif, uji asumsi klasik, analisis regresi berganda, dan uji hipotesis.

Model persamaan regresi yang secara sistematis dapat dirumuskan sebagai berikut:

\section{$Y=a+b 1 \times 1+b 2 \times 2+b 3 \times 3+b 4 \times 4+e$}

Keterangan :

$$
\begin{array}{ll}
\mathrm{Y} & =\text { Struktur Modal } \\
\mathrm{a} & =\text { Koefisien Konstanta } \\
\mathrm{b} 1, \mathrm{~b} 2, \mathrm{~b} 3, \mathrm{~b} 4 & =\text { Koefisien Regresi } \\
\mathrm{X} 1 & =\text { Likuiditas } \\
\mathrm{X} 2 & =\text { Pertumbuhan Penjualan }
\end{array}
$$




$$
\begin{aligned}
& \text { X3 = Ukuran Perusahaan } \\
& \text { X4 }=\text { Struktur Asset } \\
& \mathrm{e}=\text { Error }
\end{aligned}
$$

Pengujian hipotesis dengan membandingkan hasil t-statistik dengan $\mathrm{t}$ tabel atau dengan nilai $\mathrm{p}$ value.(Suliyanto,2018).

\section{PEMBAHASAN}

\section{Analisis Deskriptif}

Statistik deskriptif dalam penelitian ini dilihat dari nilai rata-rata (mean), standar deviasi, nilai maksimum, dan nilai minimum (Ghozali, 2011: 19). Hasil Analisis deskriptif bisa dilihat

\begin{tabular}{|c|c|c|c|c|c|c|c|}
\hline & \multirow{2}{*}{$\begin{array}{c}\mathrm{N} \\
\text { Statistic }\end{array}$} & \multirow{2}{*}{$\begin{array}{r}\text { Range } \\
\text { Statistic }\end{array}$} & \multirow{2}{*}{$\begin{array}{c}\text { Minimum } \\
\text { Statistic }\end{array}$} & \multirow{2}{*}{$\begin{array}{c}\text { Maximum } \\
\text { Statistic } \\
\end{array}$} & \multicolumn{2}{|c|}{ Mean } & \multirow{2}{*}{$\begin{array}{c}\text { Std. } \\
\text { Deviation } \\
\text { Statistic }\end{array}$} \\
\hline & & & & & Statistic & Std. Error & \\
\hline DER & 72 & $\begin{array}{c}3.31746567 \\
8\end{array}$ & .0053838296 & 3.32284951 & $\begin{array}{c}.26899785 \\
5\end{array}$ & .0477148 & $\begin{array}{c}.40487309 \\
5\end{array}$ \\
\hline $\mathrm{CR}$ & 72 & $\begin{array}{c}42.6011284 \\
3\end{array}$ & .5002801650 & 43.1014086 & $\begin{array}{c}3.4776105 \\
4\end{array}$ & $\begin{array}{c}.62123748 \\
3\end{array}$ & $\begin{array}{c}5.2713748 \\
4\end{array}$ \\
\hline $\mathrm{TP}$ & 72 & $\begin{array}{c}1.34510819 \\
6\end{array}$ & $\begin{array}{c}- \\
1.000000000\end{array}$ & .345108197 & -.00648820 & $\begin{array}{c}.02287671 \\
2\end{array}$ & $\begin{array}{c}.19411534 \\
1\end{array}$ \\
\hline FS & 72 & $\begin{array}{c}2.23645260 \\
7\end{array}$ & 11.75517824 & 13.9916309 & $\begin{array}{c}12.892271 \\
8\end{array}$ & $\begin{array}{c}.08609184 \\
5\end{array}$ & $\begin{array}{c}.73051352 \\
6\end{array}$ \\
\hline SA & 72 & $\begin{array}{c}.563741698 \\
2\end{array}$ & .0424561333 & 606197832 & $\begin{array}{c}.28587809 \\
1\end{array}$ & $\begin{array}{c}.01873646 \\
0\end{array}$ & $\begin{array}{c}.15898413 \\
0\end{array}$ \\
\hline $\begin{array}{l}\text { Valid N } \\
\text { (listwis } \\
\text { e) }\end{array}$ & 72 & & & & & & \\
\hline
\end{tabular}
dari tabel berikut:

Tabel 2. Hasil Deskriptif

Sumber : data diolah 2020

Berdasarkan tabel 2 diatas dapat diketahui bahwa data yang diteliti berjumlah 72. Nilai struktur modal (DER) menunjukan rata-rata struktur modal (DER) Perusahaan Food and Beverage yang terdaftar di Bursa Efek Indonesia (BEI) tahun 2017-2019 sebesar 0,0477148, nilai terendah 0,0053838296, nilai tertinggi 3,32284951 dan standar deviation sebesar 0,404873095.

Nilai likuiditas (CR) menunjukkan rata-rata likuiditas (CR) Perusahaan Food and Beverage yang terdaftar di Bursa Efek Indonesia (BEI) tahun 2017-2019 sebesar 0,621237483, nilai terendah 0,5002801650 , nilai tertinggi 43,1014086, dan standar deviation sebesar 5,27137484 .

Nilai pertumbuhan penjualan (TP) menunjukan rata-rata pertumbuhan penjualan (TP) Perusahaan Food and Beverage yang terdaftar di Bursa Efek Indonesia (BEI) tahun 2017-2019 sebesar 0,022876712, nilai terendah $-1,000000000$, nilai tertinggi 0,345108197 , dan standar deviation sebesar 0,194115341 . 
Nilai ukuran perusahaan (firm size) menunjukan rata-rata ukuran perusahaan (firm size) Perusahaan Food and Beverage yang terdaftar di Bursa Efek Indonesia (BEI) tahun 2017-2019 sebesar 0,86091845 , nilai terendah 11,75517824 , nilai tertinggi 13,9916309 , dan standar deviation sebesar 0,73513526 .

Nilai struktur asset (SA) menunjukan rata-rata struktur aktiva (SA) Perusahaan Food and Beverage yang terdaftar di Bursa Efek Indonesia (BEI) tahun 2017-2019 sebesar 0,018736460, nilai terendah 0,424561333, nilai tertinggi 0,606197832, dan standar deviation sebesar 0,158984130 .

\section{Uji Asumsi Klasik}

\section{Uji Normalitas}

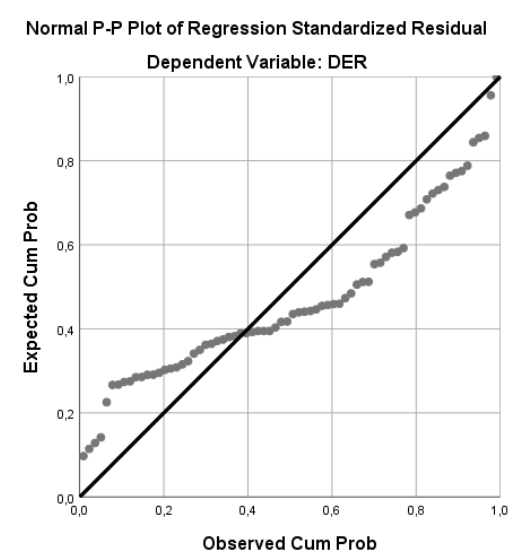

Gambar 3. Uji Normalitas

Dari gambar 3 menunjukkan bahwa plotting data tidak jauh dari garis diagonalnya. Hal ini berarti bahwa data berdistribusi normal.

\section{Uji Multikolinearitas}

Tabel 3. Hasil Uji Multikolinearitas

\begin{tabular}{llll}
\hline & & \multicolumn{2}{c}{ Collinearity Statistics } \\
Model & & Tolerance & VIF \\
\hline 1 & (Constant) & & \\
& CR & .372 & 2.688 \\
& TP & .428 & 2.337 \\
& FS & .734 & 1.362 \\
& SA & .654 & 1.528 \\
\hline
\end{tabular}

a. Dependent Variable : DER

Sumber : data diolah, 2020. 
Dari tabel 3 diatas terlihat setiap variabel bebas mempunyai nilai tolerance $\geq$ 0,1 dan nilai VIP $\leq 10$. Jadi dapat disimpulkan bahwa tidak ada multikolinearitas antar variabel bebas dalam model regresi ini.

\section{Uji Autokorelasi}

Tabel 4. Hasil Uji Autokorelasi

Model Summary ${ }^{\mathbf{b}}$

\begin{tabular}{crrrrr}
\hline Model & R & R Square & $\begin{array}{c}\text { Adjusted R } \\
\text { Square }\end{array}$ & $\begin{array}{l}\text { Std. Error of } \\
\text { the Estimate }\end{array}$ & Durbin-Watson \\
\hline 1 & $\begin{array}{rrrrr}458 \\
\text { a }\end{array}$ & .210 & .163 & .3704852387 & 2.245 \\
& & & & & \\
\hline
\end{tabular}

a. Predictors: (Constant), SA, Firm Size, TP, CR

Berdasarkan tabel 4 diketahui nilai Durbin Watson (D-W) sebesar 2,245, oleh karena itu DW 2,245 lebih besar dari batas atas (du) yaitu 0 (nol) dan kurang dari $4-0$ (2-du), sehingga disimpulkan tidak terjadi autokorelasi positif maupun negatif $(\mathrm{du}<\mathrm{d}<4-\mathrm{du})$.

\section{Uji Heteroskedastisitas}

Tabel 5. Hasil Uji Heteroskedastisitas

\begin{tabular}{cccc} 
& & M & Sig. \\
\hline 1 & $($ Constant $)$ & -1.404 & .165 \\
& CR & -2.253 & .028 \\
& TP & -3.225 & .002 \\
& FS & 1.675 & .099 \\
& SA & 1.017 & .313 \\
\hline
\end{tabular}

Sumber : data diolah, 2020.

Dari tabel 5 diatas diketahui bahwa nilai signifikansi atau Sig. Variabel likuiditas (X1) sebesar 0,028, variabel pertumbuhan penjualan (X2) sebesar 0,002 berarti variabel independen (X1) dan (X2) lebih kecil dari 0,05 maka dapat disimpulkan bahwa terdapat gejala heteroskedastisitas. Sedangkan, variabel ukuran perusahaan (X3) sebesar 0,099, dan struktur aktiva (X4) sebesar 0,313. berarti variabel independen (X3) dan (X4) lebih besar dari 0,05 maka dapat disimpulkan bahwa tidak terdapat gejala heteroskedastisitas. Artinya model regresi yang dipakai untuk penelitian ini layak untuk dilakukan. 


\section{JURNAL AKUNTANSI, Vol. 10, No. 2, November (2021)}

\section{Analisis Regresi Linear Berganda}

Tabel 6. Hasil Uji Regresi Linear Berganda

\section{Coefficients $^{\mathrm{a}}$}

\begin{tabular}{|c|c|c|c|c|c|c|}
\hline & & \multicolumn{2}{|c|}{$\begin{array}{c}\text { Unstandardized } \\
\text { Coefficients }\end{array}$} & \multirow{2}{*}{$\begin{array}{c}\text { Standardized } \\
\text { Coefficients } \\
\text { Beta } \\
\end{array}$} & \multirow[b]{2}{*}{$\mathrm{t}$} & \multirow[b]{2}{*}{ Sig. } \\
\hline \multicolumn{2}{|c|}{ Model } & B & Std. Error & & & \\
\hline \multirow[t]{5}{*}{1} & (Constant) & -1.247 & .888 & & -1.404 & .165 \\
\hline & $\mathrm{CR}$ & -.031 & .014 & -.401 & -2.253 & .028 \\
\hline & $\mathrm{TP}$ & -1.117 & .346 & -.535 & -3.225 & .002 \\
\hline & FS & .118 & .070 & .212 & 1.675 & .099 \\
\hline & SA & .348 & .342 & .137 & 1.017 & .313 \\
\hline
\end{tabular}

a. Dependent Variable: DER

Sumber : data diolah, 2020.

Dari hasil analisis dengan program SPSS versi 25.0, maka dapat diketahui persamaan regresi dari penelitian ini adalah :

$$
\mathrm{Y}=-1,247+0,031 \mathrm{X} 1-1,117 \mathrm{X} 2+0,118 \mathrm{X} 3+0,348 \mathrm{X} 4
$$

Analisis persamaan regresi linear berganda di atas adalah sebagai berikut

a. Koefisien konstanta sebesar -1,247 menunjukkan bahwa jika semua variabel independen (likuiditas, pertumbuhan penjualan, ukuran perusahaan, dan struktur aktiva) menunjukkan nilai nol, maka kemungkinan praktik struktur modal sebesar 1,247

b. Koefisien regresi likuiditas (X1) sebesar -0,031 menunjukkan bahwa setiap peningkatan 1 persen likuiditas, maka struktur modal akan mengalami penurunan sebesar 0,031.

c. Koefisien regresi pertumbuhan penjualan (X2) sebesar -1,117 menunjukkan bahwa setiap peningkatan 1 persen pertumbuhan penjualan, maka struktur modal akan mengalami penurunan sebesar 1,117 .

d. Koefisien ukuran perusahaan (X3) sebesar 0,118 menunjukkan bahwa setiap peningkatan 1 persen ukuran perusahaan, maka struktur modal akan mengalami peningkatan sebesar 0,118 .

e. Koefisien struktur asset (X4) sebesar 0,348 menunjukkan bahwa setiap peningkatan 1 persen struktur asset, maka struktur modal akan mengalami peningkatan sebesar 0,012. 


\section{Studi Uji Signifikansi}

Uji Signifikansi Secara Parsial (Uji t)

Tabel 7. Hasil Uji Signifikansi / Uji t

\section{Coefficients $^{\mathrm{a}}$}

\begin{tabular}{|c|c|c|c|c|c|c|}
\hline & & \multicolumn{2}{|c|}{$\begin{array}{c}\text { Unstandardized } \\
\text { Coefficients }\end{array}$} & \multirow{2}{*}{$\begin{array}{c}\begin{array}{c}\text { Standardized } \\
\text { Coefficients }\end{array} \\
\text { Beta } \\
\end{array}$} & \multirow[b]{2}{*}{$\mathrm{t}$} & \multirow[b]{2}{*}{ Sig. } \\
\hline \multicolumn{2}{|c|}{ Model } & B & Std. Error & & & \\
\hline \multirow[t]{5}{*}{1} & (Constant) & -1.247 & .888 & & -1.404 & .165 \\
\hline & CR & -.031 & .014 & -.401 & -2.253 & .028 \\
\hline & $\mathrm{TP}$ & -1.117 & .346 & -.535 & -3.225 & .002 \\
\hline & FS & .118 & .070 & .212 & 1.675 & .099 \\
\hline & SA & .348 & .342 & 137 & 1.017 & .313 \\
\hline
\end{tabular}

a. Dependent Variable: DER

Sumber : data diolah, 2020.

1) Pengujian hipotesis 1

Dari tabel 7 di atas, nilai t hitung likuiditas (CR) X1 adalah sebesar -2,253 dan nilai signifikansi lebih kecil dari 0,05 yaitu sebesar 0,028 . Hal ini menunjukkan bahwa variabel likuiditas (X1) berpengaruh signifikan terhadap struktur modal pada Perusahaan Food and Beverage yang terdaftar di Bursa Efek Indonesia tahun 2017-2019, sehingga hipotesis pertama diterima.

2) Pengujian hipotesis 2

Dari tabel 7 di atas, nilai t hitung pertumbuhan penjualan (TP) X2 adalah sebesar -3,225 dan nilai signifikan lebih kecil dari 0,05 yaitu sebesar 0,002 . Hal ini menunjukkan bahwa variabel pertumbuhan penjualan (X2) berpengaruh signifikan terhadap struktur modal pada Perusahaan Food and Beverage yang terdaftar di Bursa Efek Indonesia tahun 2017-2019, sehingga hipotesis kedua diterima.

3) Pengujian hipotesis 3

Dari tabel 7 di atas, nilai thitung ukuran perusahaan (firm size) X3 adalah sebesar 1,675 dan nilai signifikansi lebih besar dari 0,05 yaitu sebesar 0,099. Hal ini menunjukkan bahwa variabel ukuran perusahaan (X3) tidak berpengaruh signifikan terhadap struktur modal pada Perusahaan Food and Beverage yang terdaftar di Bursa Efek Indonesia tahun 2017-2019, sehingga hipotesis ketiga ditolak.

4) Pengujian hipotesis 4

Dari tabel 7 di atas, nilai t hitung struktur asset (SA) X4 adalah sebesar 1,017 dan nilai signifikansi lebih besar dari 0,05 yaitu sebesar 0,313. Hal ini menunjukkan bahwa variabel struktur aktiva (X4) tidak berpengaruh signifikan terhadap struktur modal pada Perusahaan Food and Beverage yang terdaftar di Bursa Efek Indonesia tahun 2017-2019, sehingga hipotesis keempat ditolak. 


\section{JURNAL AKUNTANSI, Vol. 10, No. 2, November (2021)}

\section{Uji Signifikansi Secara Simultan (Uji F)}

Tabel 8. Hasil Uji Signifikansi / Uji F

\begin{tabular}{lccccc}
\multicolumn{5}{c}{ ANOVA $^{\mathrm{a}}$} \\
\multicolumn{1}{c}{ Model } & $\begin{array}{l}\text { Sum of } \\
\text { Squares }\end{array}$ & Df & $\begin{array}{c}\text { Mean } \\
\text { Square }\end{array}$ & F & Sig. \\
\hline Regression & 2.442 & 4 & .611 & 4.448 & $.003^{\mathrm{b}}$ \\
Residual & 9.196 & 67 & .137 & & \\
Total & 11.638 & 71 & & & \\
a. Dependent Variable: DER & & & & \\
b. Predictors: (Constant), SA, TP, FS, CR & & & & \\
\hline
\end{tabular}

Dari tabel 8 di atas diperoleh nilai $\mathrm{F}$ hitung sebesar 4,448 dan nilai signifikan 0,003. Karena nilai signifikan $(0,003)$ lebih kecil dari 0,05 maka likuiditas, pertumbuhan penjualan, ukuran perusahaan, dan struktur aktiva secara bersama-sama berpengaruh signifikan terhadap struktur modal. Artinya, bahwa ada pengaruh secara bersama-sama ke empat variabel bebas pada penelitian ini terhadap variabel terikat yaitu struktur modal.

\section{Koefisien Determinasi}

Tabel 9. Hasil Koefisien Determinasi

Model Summary ${ }^{b}$

\begin{tabular}{|c|c|c|c|c|c|}
\hline Model & $\mathrm{R}$ & R Square & $\begin{array}{l}\text { Adjusted R } \\
\text { Square }\end{array}$ & $\begin{array}{l}\text { Std. Error of } \\
\text { the Estimate }\end{array}$ & Durbin-Watson \\
\hline 1 & $\begin{array}{r}.458 \\
\mathrm{a}\end{array}$ & .210 & .163 & .3704852387 & 2.245 \\
\hline
\end{tabular}

a. Predictors: (Constant), SA, Firm Size, TP, CR

Sumber : data diolah, 2020.

Dari tabel 9 di atas angka koefisien determinasi (Adjusted $R$ Square) sebesar 0,163. Hal ini bahwa variabel likuiditas, pertumbuhan penjualan, ukuran perusahaan, dan struktur aktiva mempunyai peran $16,3 \%$ secara bersama-sama untuk dapat menjelaskan atau menerangkan variabel struktur modal. Sedangkan sisanya sebesar $83,7 \%$ dijelaskan oleh variabel lain yang tidak diteliti dalam penelitian ini.

Hasil penelitian variabel likuiditas berpengaruh signifikan terhadap struktur modal. Hasil penelitian ini mendukung teori pecking order bahwa tingkat likuiditas yang tinggi harus digunakan perusahaan untuk berhati hati terhadap tingginya tingkat hutang. Artinya meskipun tingkat likuiditas baik, perusahaan tidak serta merta meningkatkan hutangnya tetapi lebih mengedepankan modal sendiri dalam pembiayaan operasional perusahaan. Hasil ini tidak sesuai 
dengan teori trade off bahwa semakin tinggi tingkat likuiditas kesempatan tingkat hutang semakin tinggi. Dan ini sesuai dengan penelitian terdahulu (Mishra \& Dasgupta, 2019), (Ramli et al., 2019), (Bilgin \& Dinc, 2019), (Gunardi et al., 2020).

Tingkat pertumbuhan yang diproksikan dengan pertumbuhan penjualan menunjukkan hasil signifikan terhadap struktur modal. Hal ini mendukung teori trade off bahwa perusahaan dengan peluang pertumbuhan tinggi cenderung lebih sedikit meminjam dibandingkan dengan perusahaan yang beraset tinggi. Ini sesuai hasil penelitian terdahulu dari (Ramli et al., 2019), (Zhang \& Liu, 2017), (Panda \& Nanda, 2020).

Hasil penelitian menunjukkan ukuran perusahaan tidak berpengaruh terhadap struktur modal perusahaan. Perusahaan besar lebih mudah terpantau oleh semua investor pasar modal. Biaya yang lebih rendah dapat dilakukan oleh perusahaan besar saat mereka menerbitkan ekuitas. Dan ini berarti tingkat hutang yang rendah. Hal ini akan mendukung gagasan teori packing order dan sesuai dengan hasil penelitian terdahulu yaitu (Yildirim et al., 2018), (Ramli et al., 2019).

Pembiayaan hutang lebih banyak dengan menggunakan aset berwujud sesuai teori trade off, sedangkan pembiayaan ekuitas lebih banyak menggunakan asset tidak berwujud. Dimungkinkan terjadi keseimbangan antara rasio hutang dan ekuitas.(Charity et al., 2019). Hasil penelitian menunjukkan bahwa struktur asset tidak berpengaruh terhadap struktur modal, hal ini mendukung teori pecking order dan sesuai hasil penelitian (Panda \& Nanda, 2020) dan (Zhang \& Liu, 2017).

\section{PENUTUP}

\section{Simpulan}

Hasil penelitian menunjukkan bahwa hipotesis pertama terbukti, terdapat pengaruh negative signifikan tingkat likuiditas terhadap struktur modal. Hal ini sesuai dengan teori Trade Off bahwa perusahaan dengan tingkat likuiditas tinggi bisa menimbulkan hutang yang tinggi dengan kemampuan membayar hutangnya.

Hipotesis kedua terbukti terdapat pengaruh negative signifikan tingkat pertumbuhan penjualan terhadap struktur modal. Hal ini sesuai dengan teori pecking order, pertumbuhan berdampak positif terhadap hutang. Semakin tinggi pertumbuhan perusahaan maka biaya kesulitan keuangan juga semakin tinggi dan ini dipenuhi dengan pembiayaan eksternal.

Hipotesis ketiga dan keempat tidak terbukti pada penelitian ini. Ukuran perusahaan dan struktur aset tidak berpengaruh terhadap hutang. Dengan hasil ini maka hasil tersebut sesuai dengan teori pecking order, dimana perusahaan besar sangat mudah terpantau di pasar modal dan asymetri informasi bisa ditekan serendah mungkin. Dengan demikian perusahaan lebih banyak mengeluarkan pendanaan internal dengan biaya rendah dan hutang yang rendah. Demikian pula struktur asset disini ternyata ternyata tidak berpengaruh terhadap tingkat hutang perusahaan. Hal ini menjelaskan bahwa teori pecking order tidak eksplisit yang dijelaskan oleh beberapa peneliti.

\section{Saran}

Melihat hasil penelitian maka lebih baik perusahaan bisa meningkatkan diversifikasi perusahaan. Perusahaan besar yang memiliki diversifikasi yang baik maka memiliki resiko kebangkrutan yang rendah. Perusahaan berukuran besar berarti memiliki aset yang besar, hal ini nantinya bisa meningkatkan kesempatan mendapatkan pendanaan eksternal yang lebih besar. 


\section{REFERENSI}

Bilgin, R., \& Dinc, Y. (2019). Factoring as a determinant of capital structure for large firms: Theoretical and empirical analysis. Borsa Istanbul Review, 19(3), 273-281. https://doi.org/10.1016/j.bir.2019.05.001

Charity, E., Austin, O. C., Orji, O. C., Steve, E. E., \& Okechukwu, A. J. (2019). Capital structure determinants and performance of startup firms in developing economies: A conceptual review. Academy of Entrepreneurship Journal, 25(3), 1-10.

Gunardi, A., Firmansyah, E. A., Widyaningsih, I. U., \& Rossi, M. (2020). Capital structure determinants of construction firms: Does firm size moderate the results? Montenegrin Journal of Economics, 16(2), 93-100. https://doi.org/10.14254/1800-5845/2020.16-2.7

Jensen, M. C. (1986). American Economic Association Agency Costs of Free Cash Flow , Corporate Finance, and Takeovers Author ( s ): Michael C . Jensen Source : The American Economic Review, Vol . 76, No. 2, Papers and Proceedings of the Ninety-Eighth Annual Meeting of the. The American Economic Review, 76(2), 323-329. http://www.jstor.com/stable/1818789

Khémiri, W., \& Noubbigh, H. (2018). Determinants of capital structure: Evidence from subSaharan African firms. Quarterly Review of Economics and Finance, 70, 150-159. https://doi.org/10.1016/j.qref.2018.04.010

Kraus, A., \& Litzenberger, R. H. (1973). a State-Preference Model of Optimal Financial Leverage. In The Journal of Finance (Vol. 28, Issue 4, pp. 911-922). https://doi.org/10.1111/j.1540-6261.1973.tb01415.x

Miller, F. M. and M. H. (1963). Corporate Income Taxes and the Cost of Capital : A Correction Author ( s ): Franco Modigliani and Merton H . Miller Source: The American Economic Review, Jun ., 1963, Vol . 53 , No . 3 ( Jun ., 1963 ), pp . 433- Published by: American Economic Associa. The American Economic Review, 53(3), 433-443. http://www.jstor.com/stable/1818789

Mishra, S., \& Dasgupta, R. (2019). Cross-impact of leverage and firm performance: developed vs frontier bank-based economies. Managerial Finance, 45(8), 982-1000. https://doi.org/10.1108/MF-09-2018-0435

Myers, S. C. (1983). Stwr C. Myers.

Nguyen, H. T., \& Nguyen, A. H. (2020). The impact of capital structure on firm performance: Evidence from Vietnam. Journal of Asian Finance, Economics and Business, 7(4), 97-105. https://doi.org/10.13106/JAFEB.2020.VOL7.NO4.97

Panda, A. K., \& Nanda, S. (2020). Determinants of capital structure; a sector-level analysis for Indian manufacturing firms. International Journal of Productivity and Performance Management, 69(5), 1033-1060. https://doi.org/10.1108/IJPPM-12-2018-0451

Ramli, N. A., Latan, H., \& Solovida, G. T. (2019). Determinants of capital structure and firm financial performance-A PLS-SEM approach: Evidence from Malaysia and Indonesia. Quarterly Review of Economics and Finance, 71, 148-160. https://doi.org/10.1016/j.qref.2018.07.001

Sikveland, M., \& Zhang, D. (2020). Determinants of capital structure in the Norwegian salmon $\begin{array}{llll}\text { aquaculture industry. Marine Policy, } & 119 \text { (June), } & 104061 .\end{array}$ https://doi.org/10.1016/j.marpol.2020.104061

Vo, X. V. (2017). Determinants of capital structure in emerging markets: Evidence from Vietnam. 
Research in International Business and Finance, 40, 105-113. https://doi.org/10.1016/j.ribaf.2016.12.001

Yildirim, R., Masih, M., \& Bacha, O. I. (2018). Determinants of capital structure: evidence from Shari'ah compliant and non-compliant firms. Pacific Basin Finance Journal, 51(July), 198219. https://doi.org/10.1016/j.pacfin.2018.06.008

Zhang, D., \& Liu, D. (2017). Determinants of the capital structure of Chinese non-listed enterprises: Is TFP efficient? Economic Systems, 41(2), 179-202. https://doi.org/10.1016/j.ecosys.2016.12.003 